\title{
ANALYSIS OF THE IMPLEMENTATION OF MANAGEMENT ACCOUNTING INFORMATION SYSTEMS IN THE DECISION-MAKING PROCESS OF HOTEL TOURISM BUSINESS AND TRAVEL AGENTS IN NORTH MINAHASA
}

\author{
Maykel A. Tampenawas, Raymond F. Rombot, Johanes H. Tene, Denny I. Y. Rompas \\ Department of Accounting, Polytechnic of Manado Country \\ DOI: $10.31364 / \mathrm{SCIRJ} / \mathrm{v} 8.19 .2020 . P 0920809$ \\ http://dx.doi.org/10.31364/SCIRJ/v8.i9.2020.P0920809
}

\begin{abstract}
The purpose of this research is to determine how the application of management accounting information systems in the decision-making process in the hotel tourism business and travel agents in North Minahasa. This research method is carried out using qualitative research methods, focusing more on how the application of management accounting information systems in the decisionmaking process in tourism businesses, especially hotels and travel agents in North Minahasa Regency. The approach used in this research is a qualitative descriptive approach with the intention that researchers can describe clearly, in detail, and in depth about the situation and factual conditions in the field, in accordance with the prevailing scientific norms. The sampling technique used by the researcher is purposive sampling, which is a purposive sampling technique (consciously) of a number of people who are key informants, namely people who are considered to know the substance being studied correctly (Sugiyono, 2012). Key informants are 15 people who have clear, accurate, and reliable information in the form of statements, information or data that can help in understanding the problem or problem. Details of the number of samples in this study consisted of: representatives from hotels in North Minahasa (10 people), and; Representatives from travel agencies in North Minahasa (5 people). The types of data in this study are primary data and secondary data. Primary data were obtained from tourism businesses in North Minahasa, especially hospitality businesses and travel agents. As for secondary data as a complement to information obtained indirectly, namely through journal literature, internet sources, interview results and publication data from the North Minahasa Regency Government and the North Minahasa Central Statistics Agency, which are related to the focus of research studies. All data and information were obtained through survey methods and direct field observations. The results show that the application of management accounting information systems in the decision-making process in the tourism business of hotels and travel agents in North Minahasa is in accordance with the provisions in dealing with situations, conditions and challenges that exist in the current industrial era 4.0.
\end{abstract}

Keywords: Management Accounting Information System, Decision Making, Hotel, Travel Agent

\section{INTRODUCTION}

The tourism sector in Indonesia is currently experiencing a positive growth trend. According to data obtained from the Central Statistics Agency in October 2019, it shows the level of the number of foreign tourist arrivals entering Indonesia, reaching IDR 1.35 million. This shows that the contribution obtained from the tourism sector to state revenue is very potential. It is known that the source of state revenue originating from the industrial sector is one of the largest after the oil and gas industry sector revenue in the non-tax state revenue group. Therefore, it requires serious attention from all parties, not only from the government, or related state agencies. However, it also requires the involvement of all elements in society to support one of these mainstay sectors. For this reason, strategic, systematic and synergistic steps are needed between the parties involved in building the tourism industry sector. For example, between the government and the private sector, or the government and tourism business actors, both from within and outside the country, as has happened and has been around for a long time.

www.sciri.org

(C) 2020, Scientific Research Journal

http://dx.doi.org/10.31364/SCIRJ/v8.i9.2020.P0920809

This publication is licensed under Creative Commons Attribution CC BY. 
North Sulawesi is one of the provinces that collaborates with domestic and foreign tourism businesses because North Sulawesi Province is currently the main tourist destination for local and foreign tourists. There are many famous tourist objects in North Sulawesi, so that they become an attraction for tourists to come to visit. One of the well-known tourist sites and the pride of the community and local government, namely the Bunaken Marine Park. In addition, there are many other tourist objects or tourist attractions in North Sulawesi Province which are scattered in almost all districts and cities.

Therefore, the existence of tourism facilities and infrastructure certainly needs to be properly and properly prepared, in order to meet the needs of tourists who come to visit. To support the tourism sector so that it can run well and smoothly, management needs effective tools for its operations, especially in dealing with various situations and challenges such as in the current era of the industrial revolution 4.0. One of the tools that are considered effective for this is the management accounting information system. This system can be used by any management in carrying out business activities, one of which is the tourism business. Therefore, it requires sufficient knowledge and understanding of the system so that its use can help the company achieve its goals.

This research was conducted with the intention of examining and analyzing the application of management accounting information systems in the tourism sector, especially hotels and travel agents in North Minahasa Regency. Based on the description above, the proposing team is interested in conducting research on how to apply management accounting information systems in the decision-making process in tourism businesses, especially hotels and travel agents in North Minahasa Regency.

\section{RESEARCH METHODS}

This research method is carried out using qualitative methods, digging information about how the application of management accounting information systems, in the decision-making process in tourism businesses, especially hotels and travel agents in North Minahasa Regency. The approach used in this research is a qualitative descriptive approach with the intention that researchers can describe clearly, in detail and in depth the factual situations and conditions in the field, in accordance with the prevailing scientific norms. In terms of its designation, the use of this method is carried out with reasons to answer questions to problems and to confirm the research objectives that have been formulated at the beginning, namely about how to apply management accounting information systems in the decision-making process in tourism businesses, especially hotels and travel agents in Minahasa Regency. North, especially in entering the current industrial era 4.0. Therefore, this research will require the involvement of interactive researchers with the object of research to understand the reality that occurs (Musianto, 2002). In this qualitative descriptive research method, the object of research will be analyzed, explained and described in accordance with the collected theory which will produce a conclusion. The sampling technique used by the researcher is purposive sampling, which is a purposive sampling technique (consciously) of a number of people who are key informants, namely people who are considered to know the substance being studied correctly (Sugiyono, 2012). Key informants are 15 people who have clear, accurate, and reliable information in the form of statements, information or data that can help in understanding the problem or problem. Details of the number of samples in this study consisted of: representatives from hotels in North Minahasa (10 people), and; Representatives from travel agencies in North Minahasa (5 people). The types of data in this study are primary data and secondary data. Primary data were obtained from tourism businesses in North Minahasa, especially hospitality businesses and travel agents. As for secondary data as a complement to information obtained indirectly, namely through journal literature, internet sources, interview results and publication data from the North Minahasa Regency Government and the North Minahasa Central Statistics Agency which are related to the focus of research studies. All data and information were obtained through survey methods and direct field observations

\section{DISCUSSION}

\section{Overview of North Minahasa Regency}

North Minahasa, one of the districts in North Sulawesi Province, was a district that was expanded from Minahasa Regency in 2004 with its capital, Airmadidi. According to sources from the official website of the North Minahasa District Government, it is explained that the historical record of the formation of North Minahasa Regency took place on November 20, 2003. It was carried out in a Plenary Session, the People's Representative Council of the Republic of Indonesia, led by Deputy Chairman Soetartjo Soerjogoeritno with a special event for the determination of the Bill, regarding the formation of regencies / cities in Indonesia into laws, particularly Law Number 33 of 2003 concerning the Establishment of North Minahasa District in North Sulawesi Province. Subsequently, North Minahasa Regency was inaugurated by the Minister of Home Affairs of the Republic of Indonesia Hari Sabarno on behalf of the President of the Republic of Indonesia on January 7, 2004.

North Minahasa Regency is located in North Sulawesi Province which is \pm 19 kilometers from the capital city of the province which has vast natural potential, as well as historical and cultural wealth of the region which is its main attraction. In accordance with these circumstances, North Minahasa Regency as one of Indonesia's tourist destinations in North Sulawesi Province

www.scirj.org

(C) 2020, Scientific Research Journal

http://dx.doi.org/10.31364/SCIRJ/v8.i9.2020.P0920809

This publication is licensed under Creative Commons Attribution CC BY. 
which has a vision, namely "North Minahasa to Become an Integrated, and Sustainable Agribusiness, Industry and Tourism Regency in 2021" and its motto, namely "To love, Serve and Welfare. "

\section{Tourism Sector in North Minahasa Regency}

Since it was formed into a new district in North Sulawesi Province, North Minahasa Regency has continued to race to develop its full potential, by optimizing all existing economic resources. One of the potentials that is the mainstay of the North Minahasa regional government, namely the tourism sector. This can be seen from the growing development of the tourism industry in North Minahasa Regency. Along with the emergence of the 3T phenomenon, namely (Transportation, Telecommunication and Tourism) in the world, the tourism industry in North Minahasa is able to make a positive contribution to regional income, as well as the economic welfare of the local community.

For this reason, the government is very interested in paying attention to the existence of the tourism sector. Various policy steps have been taken by the regional government to guarantee and at the same time encourage the sector to be even more optimal. In order to achieve this goal, the government and all related parties need to pay attention to various factors that affect tourism development. These factors include advances in technology, infrastructure, politics and security, as well as demographic factors.

The natural charm of North Minahasa, which is beautiful, has become an important capital for developing the tourism sector in North Minahasa. Several natural tourist objects are tourist destinations in North Minahasa, such as natural beauty, mountains, rivers, sea and beaches. Tourist destinations in North Minahasa, have been widely known by many people both from within the country and abroad. In addition, cultural factors, customs, and the diversity of local communities are also the main capital in this tourism sector. This can be seen from the harmony of the North Minahasa people, who have different ethnicities, religions and races in their daily lives.

Although there are many interesting tourist objects in North Minahasa, however, their management is not optimal. To support the activities of the tourism sector, it is necessary to increase adequate facilities and infrastructure for tourists, both tourist infrastructure and other supporting facilities.

\section{Tourist Destinations in North Minahasa}

The locations of tourist destinations in North Minahasa, are scattered in almost all existing districts. The location of tourist destinations in North Minahasa can be seen in the information obtained below. Hot water baths / showers, rafting tours, "Tumatenden" springs, Mount Klabat, Menara Kaki Dian, "Tunan" waterfall, "Pulisan" beach, Pulau Gangga Island and Marine Park, Lihaga Island, Animal Rescue Center Tasikoki, Tourism Object "Gunung Kekewang Restaurant", Pagoda Restaurant, Firdaus Beach, "Batu Nona" Tourism Object, White Sand Beach Tourism Object, Waleo Waterfall, Waleo Koki Beach, Maengket Beach Tourism Object, Tomb of the National Hero Maria Walanda Maramis, Surawaya Beach Tourism Area (Wineru Village, East Likupang District), Pal Beach Tourism (Marinsow Village, East Likupang District), Kinunang Beach (Kinunang Village, East Likupang District), Kalinaun Beach (Kalinaun Village, East Likupang District), Gangga Satu Beach (Gangga Satu Village, West Likupang District), Patuku Beach (Tarabitan Village, West Likupang District), "Pasir Timbul" Tourism Object (Nain Village, Wori District), Jere Well Tourism Object, Gazebo (Tiwoho Village, Wori District) ), Mangrove Forest (Tiwoho Village, Kec Wori's observation), Sports "Paragliding, Kima Bajo Resort and Spa (Kima Bajo Village, Wori District), Budo Village Beach Tour, Tulude Festival and Traditional Arts (Bulo Village), Paniki Island (Kulu Village))

\section{Supporting Factors for Tourism Development in North Minahasa 4.1. Tourism Business}

The tourist attraction in North Minahasa is the main capital, which is important for advancing the tourism sector which is growing and developing, as it is today. Some of the famous tourist objects include: the charm of Mount Klabat, the white sand beach on the island of Lihaga, the white sand beach of Paal, the charm of the peak of Kaki Dian, and other tourist objects that have unique attractions. Although there are many interesting tourist objects in North Minahasa. However, the management is deemed not optimal. To support the activities of the tourism sector, it is necessary to increase adequate facilities and infrastructure, for tourists both in terms of infrastructure provision for tourism, to the services provided.

\subsection{Hotel}

According to the data obtained, in 2019 North Minahasa there were the addition of 3 new star hotels to 7 star hotels, as well as a reduction in non-star hotels from 17 non-star hotels in 2018 to 13 non-star hotels in 2019. The decline and addition of these hotels is most likely due to the reclassification of hotels by the Tourism Office. The total rooms available from the existing 20 hotels, namely as many as 420 rooms. As for hotels or inns that are still able to operate and survive, even though they are in the midst of the

www.scirj.org

(C) 2020, Scientific Research Journal

http://dx.doi.org/10.31364/SCIRJ/v8.i9.2020.P0920809

This publication is licensed under Creative Commons Attribution CC BY. 
current Covid 19 pandemic, namely: Sutan Raja Hotel, Convention \& Recreation, Paradise Hotel, Golf \& Resort formerly Casabaio Paradise, La Merry Resort, Kalinaun Resort, Pulisan Jungle Beach Resort, Kinaari Resort, Bastianos Bangka Dive Resort, Coral Eye, Murex Bangka Dive Resort, Blue Bay Divers

\subsubsection{Travel Agent}

As a business entity that organizes a travel business, which acts as an intermediary in selling, or arranging services for traveling, a tour travel agent has duties including: brokering ticket bookings, managing travel documents, brokering reservations for accommodation, restaurants, facilities. tours and sells tour packages made by general travel agencies. The existence of travel agents at this time, in North Minahasa, is not too significant due to the rapid development of technology, so that it has greatly influenced the working patterns of the travel agency business itself. However, there are still some who survive and have their own place of business. The travel agents include: Manjo Tour, Air Ticketing, Hotel Vouchers, Travel Document Handling, Sales Management, Payment Solution, Report Management, 24 Hours Assistance, Fare and Price Advice, Domestic and Outbound Tour, Incentive Tour, Cruises, Travel Insurance, ANCHIS TOUR \& TRAVEL AIRMADIDI, @ AnchisTourTravel - Ticket Sales, Global Express Tours \& Travel (Rap Rap Lingkungan 1), GREAT Tour \& Travel (Jl. Raya Manado - Airmadidi), FS Tour \& Travel (Saronsong 1, Airmadidi, North Minahasa), JGreat Tour \& Travel (Jl. Raya Matungkas - Airmadidi), KAREN Tour \& Travel North Minahasa (Jl. Raya Manado Bitung)

\section{Application of Management Accounting Information Systems in Decision-Making Processes in Hotel Tourism and Travel Agencies in North Minahasa}

The main data collected in this research are primary data sourced from tourism businesses in North Minahasa, especially hotels and travel agents plus other secondary data. In collecting primary data, the researcher did this through verbalized interview techniques to key informants who were relevant to this research. In addition, in compiling a list of questions for verbal interviews the researcher is guided by the following points: Management accounting criteria such as:1).Linkage (Relevance), 2).Accuracy, 3).Timeliness, 4).Understanding, 5).Cost-Effectiveness

The overall criteria in point-1 above show an overview of the application of management accounting information systems by companies in the context of making decisions in the midst of situations and conditions, especially in the industrial era 4.0 like today. New themes in the use of management accounting information systems include:1). Activity-Based Management, 2). Customer Orientation, 3). Total Quality Management, 4). Time as an Element of Competition, 5). Efficiency, 6). Electronic Business (eBusiness)

The whole new theme in points 2 above shows an overview of the application of management accounting information systems. This should be owned by the company, in order to make decisions to face all kinds of challenges that will be faced in the future, especially in facing the industrial era 4.0 like today.

From the results of interviews that have been conducted, information is obtained about the application of management accounting information systems that exist in each business (hotels and travel agents) which in this case is the object of this study. To find an overview of how the application of management accounting information systems in order to make decisions in tourism businesses, especially hotels and travel agents, can be studied and analyzed in two parts, namely:

1. Study and analysis of the existing conditions in the industrial era 4.0 related to the application of a management accounting information system in the decision-making process in the hotel and travel agency tourism business in North Minahasa Regency. The following is a review of the research team who conducted verbal interviews with several key informants with the following results:

Table 3.1 Hotel Assessment \& Analysis Results - 1

\begin{tabular}{|c|l|c|c|c|c|c|}
\hline Number & \multicolumn{1}{|c|}{ Criteria } & $\begin{array}{c}\text { Number of } \\
\text { Questions }\end{array}$ & $\begin{array}{c}\text { Number of } \\
\text { Resources }\end{array}$ & $\begin{array}{c}\text { Number of } \\
\text { Answers }\end{array}$ & $\begin{array}{c}\text { Number of } \\
\text { Correct Answers }\end{array}$ & $\begin{array}{c}\text { Result( } \\
\%)\end{array}$ \\
\hline 1. & Linkage (Relevance) & 1 & 10 & 10 & 9 & 90 \\
\hline 2. & Accuracy & 1 & 10 & 10 & 8 & 80 \\
\hline 3. & Timeliness & 1 & 10 & 10 & 8 & 80 \\
\hline 4. & Understanding & 1 & 10 & 10 & 10 & 70 \\
\hline 5. & Cost-Effectiveness & 1 & 10 & 10 & 10 & 10 \\
\hline & Total & 5 & & 50 & 42 & \\
\hline
\end{tabular}

Source: Processed Data (2020) 
Information:

Number of informants $=10$, Number of criteria $=5$, Number of questions $=5$

informants $x$ Number of questions

$=10 \times 5=50$

Number of answers $=$ Number of

\section{Correct answer criteria:}

1. If the number of correct answers is $<50 \%$, then the application of SIAM has not been effective according to the provisions.

2. If the number of correct answers is $50 \%$ to $100 \%$, then the application of SIAM is already in effect according to the provisions.

Table 3.2 Travel Agency Study \& Analysis Results - 1

\begin{tabular}{|c|l|c|c|c|c|c|}
\hline Number & \multicolumn{1}{|c|}{ Criteria } & $\begin{array}{c}\text { Number of } \\
\text { Questions }\end{array}$ & $\begin{array}{c}\text { Number of } \\
\text { Resources }\end{array}$ & $\begin{array}{c}\text { Number of } \\
\text { Answers }\end{array}$ & $\begin{array}{c}\text { Number of } \\
\text { Correct Answers }\end{array}$ & $\begin{array}{c}\text { Result( } \\
\%)\end{array}$ \\
\hline 1. & Linkage (Relevance) & 1 & 5 & 5 & 4 & 80 \\
\hline 2. & Accuracy & 1 & 5 & 5 & 4 & 80 \\
\hline 3. & Timeliness & 1 & 5 & 5 & 3 & 60 \\
\hline 4. & Understanding & 1 & 5 & 5 & 5 & 100 \\
\hline 5. & Cost-Effectiveness & 1 & 5 & 5 & 4 & 80 \\
\hline & Total & 5 & & 25 & 20 & \\
\hline
\end{tabular}

Source: Processed Data (2020)

Information:

Number of informants $=5$, Number of criteria $=5$, Number of questions $=5$, informants $x$ Number of questions $=5 \times 5$ $=25$

Number of answers $=$ Number of

\section{Correct answer criteria:}

1. If the number of correct answers is $<50 \%$, then the application of SIAM has not been effective according to the provisions.

2. If the number of correct answers is 50\% to $100 \%$, then the application of SIAM is already in effect according to the provisions.

3. Study and analysis of challenges that arise in the industrial era 4.0 related to the application of management accounting information systems in the decision-making process in tourism, hotel and travel agency businesses in North Minahasa Regency. The following is a review of the research team who conducted verbal interviews with several key informants with the following results:

Table 3.3. Hotel Assessment \& Analysis Results - 2

\begin{tabular}{|c|l|c|c|c|c|c|}
\hline Number & \multicolumn{1}{|c|}{ Criteria } & $\begin{array}{c}\text { Number of } \\
\text { Questions }\end{array}$ & $\begin{array}{c}\text { Number of } \\
\text { Resources }\end{array}$ & $\begin{array}{c}\text { Number of } \\
\text { Answers }\end{array}$ & $\begin{array}{c}\text { Number of } \\
\text { Correct Answers }\end{array}$ & $\begin{array}{c}\text { Result( } \\
\%)\end{array}$ \\
\hline 1. & $\begin{array}{l}\text { Activity-Based } \\
\text { Management }\end{array}$ & 2 & 10 & 20 & 18 & 90 \\
\hline 2. & Customer Orientation & 2 & 10 & 20 & 19 & 95 \\
\hline 3. & $\begin{array}{l}\text { Total Quality } \\
\text { Management }\end{array}$ & 2 & 10 & 20 & 14 & 70 \\
\hline 4. & $\begin{array}{l}\text { Time as an Element of } \\
\text { Competition }\end{array}$ & 2 & 10 & 20 & 18 & 90 \\
\hline 5. & Efficiency & 2 & 10 & 20 & 20 & 100 \\
\hline 6. & $\begin{array}{l}\text { Electronic Business } \\
\text { (e-Business) }\end{array}$ & 2 & 10 & 20 & 20 & 100 \\
\hline & Total & 12 & & 120 & 109 & \\
\hline
\end{tabular}

Source: Processed Data (2020) 


\section{Information:}

Number of informants $=10$, Number of criteria $=6$, Number of questions $=12$ informants $x$ Number of questions $=10 \times 12$

Number of answers $=$ Number of $=120$

\section{Correct answer criteria:}

1. If the number of correct answers is $<50 \%$, then the application of SIAM has not been effective according to the provisions.

2. If the number of correct answers is $50 \%$ to $100 \%$, then the application of SIAM is already in effect according to the provisions.

Table 3.4. Travel Agency Study \& Analysis Results - 2

\begin{tabular}{|c|l|c|c|c|c|c|}
\hline Number & \multicolumn{1}{|c|}{ Criteria } & $\begin{array}{c}\text { Number of } \\
\text { Questions }\end{array}$ & $\begin{array}{c}\text { Number of } \\
\text { Resources }\end{array}$ & $\begin{array}{c}\text { Number of } \\
\text { Answers }\end{array}$ & $\begin{array}{c}\text { Number of } \\
\text { Correct Answers }\end{array}$ & $\begin{array}{c}\text { Result( } \\
\%)\end{array}$ \\
\hline 1. & $\begin{array}{l}\text { Activity-Based } \\
\text { Management }\end{array}$ & 2 & 5 & 10 & 80 \\
\hline 2. & Customer Orientation & 2 & 5 & 10 & 9 & 80 \\
\hline 3. & $\begin{array}{l}\text { Total Quality } \\
\text { Management }\end{array}$ & 2 & 5 & 10 & 80 \\
\hline 4. & $\begin{array}{l}\text { Time as an Element of } \\
\text { Competition }\end{array}$ & 2 & 5 & 10 & 80 \\
\hline 5. & Efficiency & 2 & 5 & 10 & 10 & 100 \\
\hline 6. & $\begin{array}{l}\text { Electronic Business } \\
\text { (e-Business) }\end{array}$ & 2 & 5 & 60 & 10 & 100 \\
\hline & Total & 12 & & 53 & \\
\hline
\end{tabular}

Source: Processed Data (2020)

Information:

Number of informants $=5$, Number of criteria $=6$, Number of questions $=12$ informants $\mathrm{x}$ Number of questions $=5 \times 12$

Number of answers $=$ Number of $=60$

\section{Correct answer criteria:}

1. If the number of correct answers is $<50 \%$, then the application of SIAM has not been effective according to the provisions.

2. If the number of correct answers is $50 \%$ to $100 \%$, then the application of SIAM is already in effect according to the provisions.

\section{CONCLUSION}

After conducting several stages of research, on the analysis of the application of management accounting information systems in the decision-making process, in the hotel tourism business and travel agents in North Minahasa. Finally, we, the research team from the Manado State Polytechnic Accounting Department, came to a conclusion. The conclusions obtained are as follows:

1. Potential tourism objects that are a mainstay in North Minahasa, mainly, namely beach tourism, followed by natural beauty (sea, mountains and rivers), historical objects / places, cultural tourism objects, sports and finally culinary.

2. From the data and information obtained, it shows that the tourism industry in North Minahasa is well developed. One of the indicators is the growing tourism business, especially hotels and travel agents.

3. Based on the data that has been processed, it shows that the application of management accounting information systems in the decision-making process in the hotel tourism business and travel agents in North Minahasa Regency, has applied according to the provisions in dealing with situations and conditions that exist in the current industrial era 4.0.

www.scirj.org

(C) 2020, Scientific Research Journal

http://dx.doi.org/10.31364/SCIRJ/v8.i9.2020.P0920809

This publication is licensed under Creative Commons Attribution CC BY. 
4. The data that has been processed shows that the application of management accounting information systems in the decisionmaking process in the hotel tourism business and travel agents in North Minahasa Regency has already applied according to the regulations, in facing the challenges that exist in the current industrial era 4.0.

\section{REFERENCES}

Analysis of the Application of Management Accounting Systems on Product Quality Control at PT. Four Brothers Manado,, Janrilius Doli Butarbutar, Herman Karamoy, Victorina Z.Tirayoh, Jurnal Riset Akuntansi Going Concern 12 (1), 2017, 187-1932, Fakultas Ekonomi dan Bisnis, Jurusan Akuntansi, Universitas Sam Ratulangi, Jl.Kampus Bahu, Manado, 95115, Indonesia

Management Accounting for Managerial Performance. Indonesian Journal of Accounting Research. Vol. 1 No.2, July, PP 141-162..

Baridwan, Zaki, 1995. Sistem Informasi Akuntansi, Edisi kedua, BPFE, Yogyakarta.

Dwi Rachmina, Shinta Wulan Sari, 2017. Management Accounting, Theory and Applications, Polimedia Publishing, Jakarta

Devie Deviesa, 2019. Management Accounting, Strategy \& Practical, Penerbit ANDI, Yogyakarta.

Halim \& Supomo, 1990. Management Accounting. First Edition. Edisi Pertama. BPFE-Yogyakarta

Hansen \& Mowen, 1997. Management Accounting. Edisi Alih Bahasa. Penerbit Erlangga-Jakarta

Ida Bagus Wyasa Putra, dkk. 2001. Hukum Bisnis Pariwisata. PT Refika Aditama, Bandung

Kautsar Riza, dkk. 2017. Management Accounting - Managerial Measurement and Decision Making Tool, Index Publisher, Jakarta

The Influence of Management Accounting Systems, Management Control Systems, and Decentralization on Managerial Performance (Empirical Studies at Rural Banks throughout the Former Surakarta Residency), Accounting Study Program, Faculty of Economics and Business, Muhammadiyah University of Surakarta, 2017

Slamet Sugiri, 2009. Management Accounting-An Introduction. Fourth Edition. UPP STIM YKPN

Sugiyono, 2008. Business Research Methods. Alfabeta Publisher, Bandung

Law No. 9 of 1990 concerning Tourism

Law No. 10 concerning Tourism

Warindrani.A.K, 2006. Management Accounting. First Edition. Graha Ilmu-Yogyakarta

Yoeti.O.A, 1996. Tourism Marketing. Angkasa Publisher, Bandung

www.scirj.org

(C) 2020, Scientific Research Journal

http://dx.doi.org/10.31364/SCIRJ/v8.i9.2020.P0920809

This publication is licensed under Creative Commons Attribution CC BY. 